\title{
Interactive comment on "The dynamics and export of dissolved organic carbon from subtropical small mountainous rivers during typhoon and non-typhoon periods" by Tsung-Yu Lee et al.
}

Tsung-Yu Lee et al.

tylee@ntnu.edu.tw

Received and published: 28 June 2017

Please see the attachment.

Please also note the supplement to this comment:

https://www.biogeosciences-discuss.net/bg-2017-105/bg-2017-105-AC1-

supplement.pdf 